\title{
SISTEM INFORMASI MONOGRAFI KECAMATAN SINGINGI
}

\author{
Nofri Wandi Al-Hafiz ${ }^{1}$, Febri Haswan ${ }^{2}$ \\ Dosen Fakultas Teknik, Program Studi Manajemen Informatika, \\ Universitas Islam Kuantan Singingi ${ }^{1,2}$ \\ Email : wandie.88one@gmail.com ${ }^{1}$, febri.haswan88@gmail.com ${ }^{2}$
}

\begin{abstract}
ABSTRAK
Monografi merupakan suatu data statistik penduduk dalam suatu wilayah. Manfaat Monografi adalah untuk mempermudah para pihak luar yang memerlukan data dari suatu wilayah. Dengan adanya sebuah sistem informasi monografi masyarakat dapat mengetahui pertumbuhan dan perkembangan wilayah dalam bentuk data statistik, selama ini pada Kantor Camat Singingi belum memiliki sebuah sistem yang dapat memberikan informasi yang akurat kepada masyarakat sekitar tentang data monografi, selain jarak dari desa ke kecamatan yang lumayan jauh pihak desa juga dalam menyampaikan laporan ke-kecamatan memakan waktu yang cukup lama sehingga waktu yang digunakan menjadi tidak efisien.
\end{abstract}

\section{Kata Kunci - Sistem Informasi, Perancangan, Monografi}

\section{PENDAHULUAN}

Diera perkembangan ilmu pengetahuan dan teknologi saat ini semakin pesat dan mempengaruhi berbagai bidang. Untuk menunjang kesuksesan serta kemudahan untuk menyelesaikan masalah dalam pengolahan data maka dibutuhkan alat penunjang yang tepat yaitu komputer. Komputer merupakan sebuah perangkat elektronik yang dapat memanipulasi informasi atau data komputer juga mampu menyimpan, mengambil, dan mengolah data. Banyak sekali pekerjaan yang dapat kita lakukan dengan menggunakan komputer mulai dari pengolahan kata, pembuatan grafik, pemecahan perhitungan-perhitungan yang rumit dan juga mencari informasi dengan bantuan dengan internet.

Internet juga dapat di gunakan sebagai penghubung secara jarak jauh dengan menggunakan jaringan komputer secara global. Di kalangan masyarakat umumnya sudah menfaatkan media internet guna mencari informasi dan berkomunikasi secara jarak jauh, segalanya seakan menjadi lebih mudah dan menjadikan lebih cepat diproses dalam berbagai hal dan salah satunya adalah penyampaian informasi dan komunikasi. Dengan menenggunakan sistem informasi berbasis web informasi yang disampaikan kepada masyarakat dapat diproses dengan cepat, salah satu contoh sistem yang sangat diperlukan oleh 


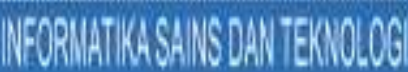

masyarakat Kecamatan Singingi adalah monografi. Monografi merupakan suatu data statistik penduduk dalam suatu wilayah.

Dengan adanya sebuah sistem informasi monografi masyarakat dapat mengetahui pertumbuhan dan perkembangan wilayah dalam bentuk data statistik, selama ini pada Kantor Camat Singingi belum memiliki sebuah sistem yang dapat memberikan informasi tentang data monografi yang akurat, selain jarak dari desa ke kecamatan yang lumayan jauh pihak desa juga dalam menyampaikan laporan ke-kecamatan memakan waktu yang cukup lama sehingga waktu yang digunakan menjadi tidak efisien. Seharusnya dizaman teknologi informasi sekarang ini pihak Kecamatan Singingi sudah memiliki media informasi tentang monografi.

\section{METODE PENELITIAN}

\section{A. Diagram Alir Proses Perancangan Sistem}

Diagram alir merupakan suatu proses yang menampilkan langkah-langkah dalam perancangan sistem monografi pada Kecamatan Singingi. Adapaun contoh diagram alir pada sistem monografi pada Kecamatan Singingi dapat dilihat pada gambar berikut :

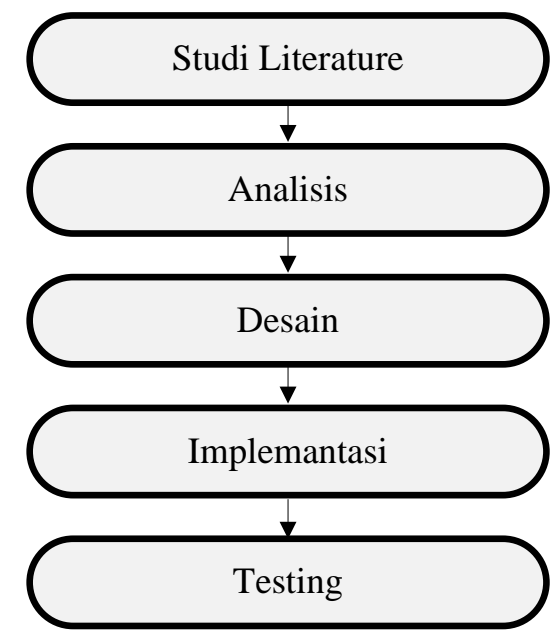

Gambar 1. Diagram Alir Proses Perancangan Sistem

\section{B. Tahap Penelitian}

Dalam penelitian dalam Perancangan Sistem Monografi Kecamatan Singingi penulis melakukan 2 tahapan penelitian yaitu, tahap pengumpulan data dan tahap pembuatan sistem.

\section{Studi Literatur}

Pada penelitian ini tentang Perancangan Sistem Monografi Kecamatan Singingi terdapat beberapa metode dalam studi literatur. 
Dalam metode ini penulis mengumpulkan berbagai data dan berbagai informasi yang terkait dengan penelitian ini.

\section{Analisis}

a) Survey Data

Pada metode ini penulis melakukan survey lokasi langsung pada istansi terkait penggambilan data tentang Monografi pada Kecamatan Singingi.

b) Hasil Survey

Data hasil survey yang sudah terkumpul di-input dianalisa kemudian dijadikan variabel yang dapat digunakan untuk pembuatan aplikasi tentang monografi pada kecamatan singingi.

\section{E. Desain}

Pada tahapan ini berfokus pada de-sain pembuatan program.

\section{F. Implementasi}

Pada tahapan implementasi ini dijelaskan secara terperinci mengenai komponen-komponen perancangan sistem dan penjelasan tentang penggunaan aplikasi monografi berbasi web pada Kecamatan Singingi.

\section{G. Testing}

Dalam tahapan ini akan dilakukan pengujian Aplikasi yang telah dibuat.

\section{HASIL DAN PEMBAHASAN}

\section{A. Rancangan Global}

Rancangan global ini menjelaskan secara global mengenai desain $U M L$ (Unifed Modelling Language) dan menggambarkan bagaimana actor (user dan admin) berinteraksi dengan sistem. Berikut adalah cara kerja actor pada UML.

\section{B. Use Case Diagram}

Berikut ini adalah gambaran umum dari Use Case Diagram perancangan sistem monografi pada Kecamatan Kuantan Singingi. 


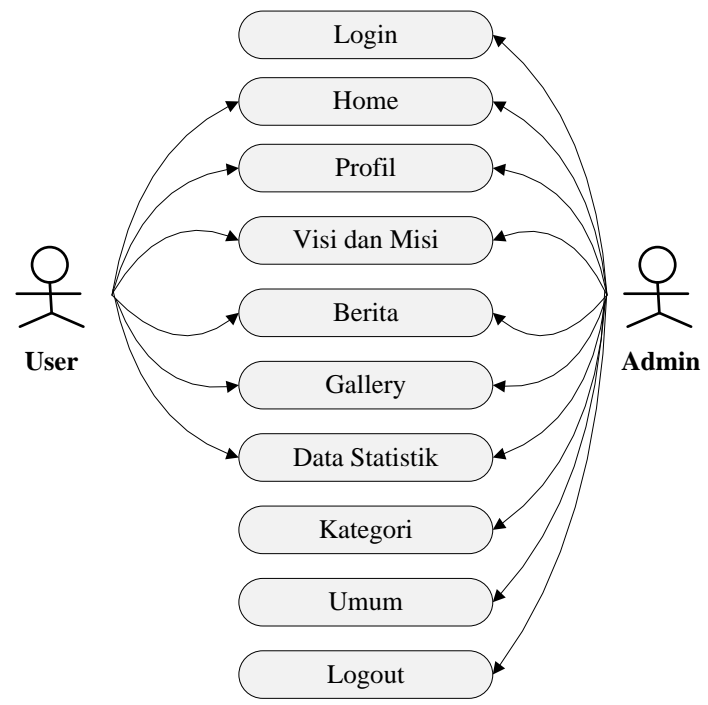

Gambar 2. Use Case Diagram

\section{Activity Diagram User}

Adapun gambaran umum Aktivity Diagram User dari perancangan sistem monografi pada Kecamatan Kuantan Singingi sebagai berikut :

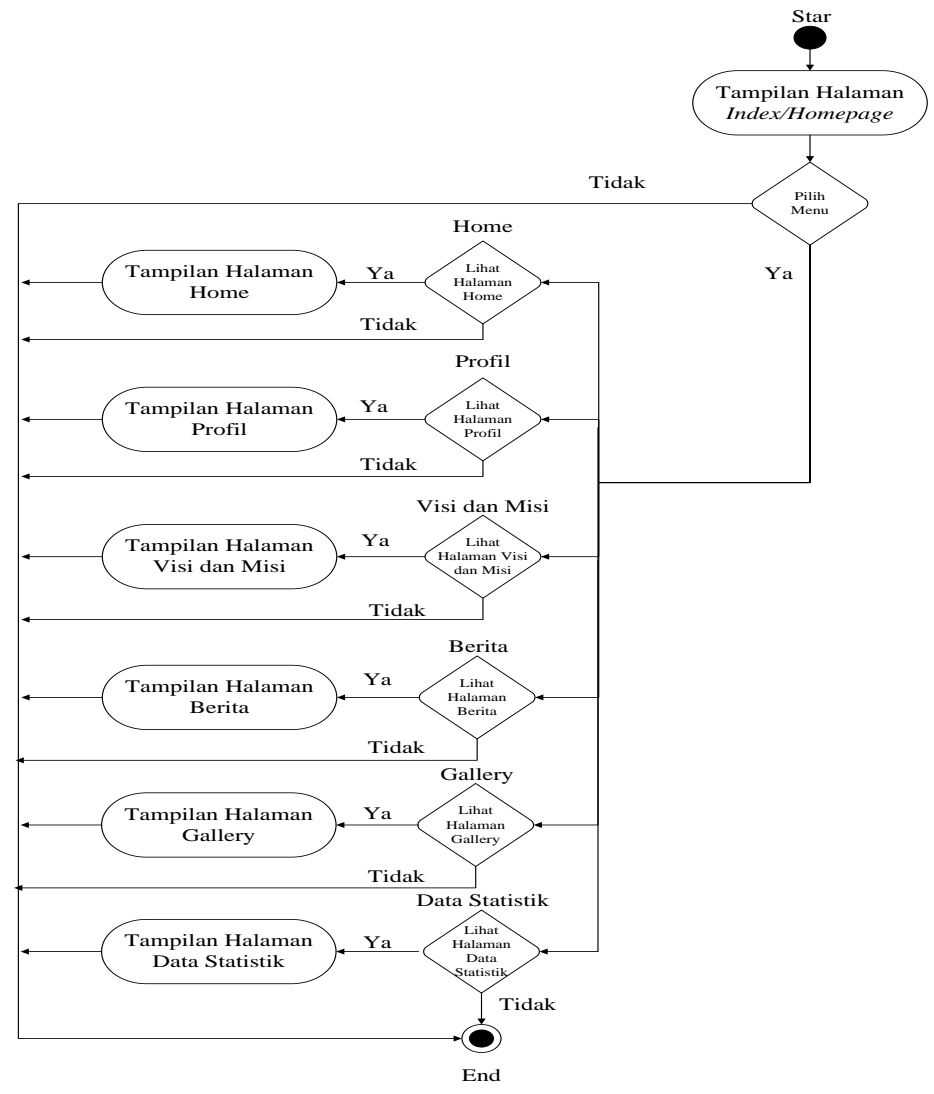

Gambar 3. Activity Diagram User 


\section{Activity Diagram Admin}

Berikut ini adalah gambaran umum Aktivity Diagram Admin dari perancangan sistem monografi pada Kecamatan Kuantan Singingi.

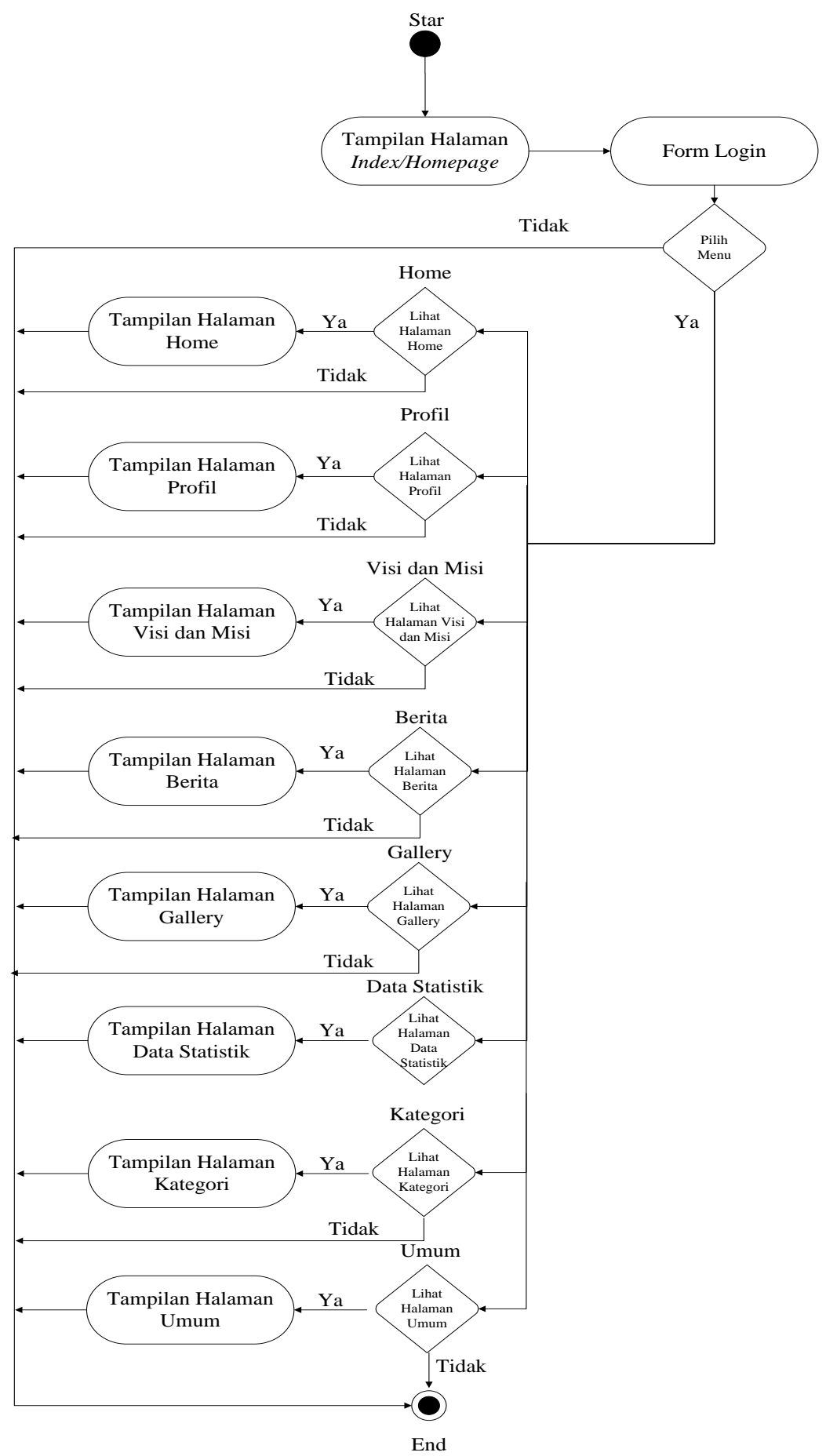

Gambar 4. Activity Diagram Admin 


\section{E. Sequence Diagram}

Sequence Diagram menggambarkan aktivitas sebuah website dalam proses alur penampilan pesan (message) yang di inputkan pada objek-objek web tersebut. Berikut ini dapat digambarkan sequence diagram.

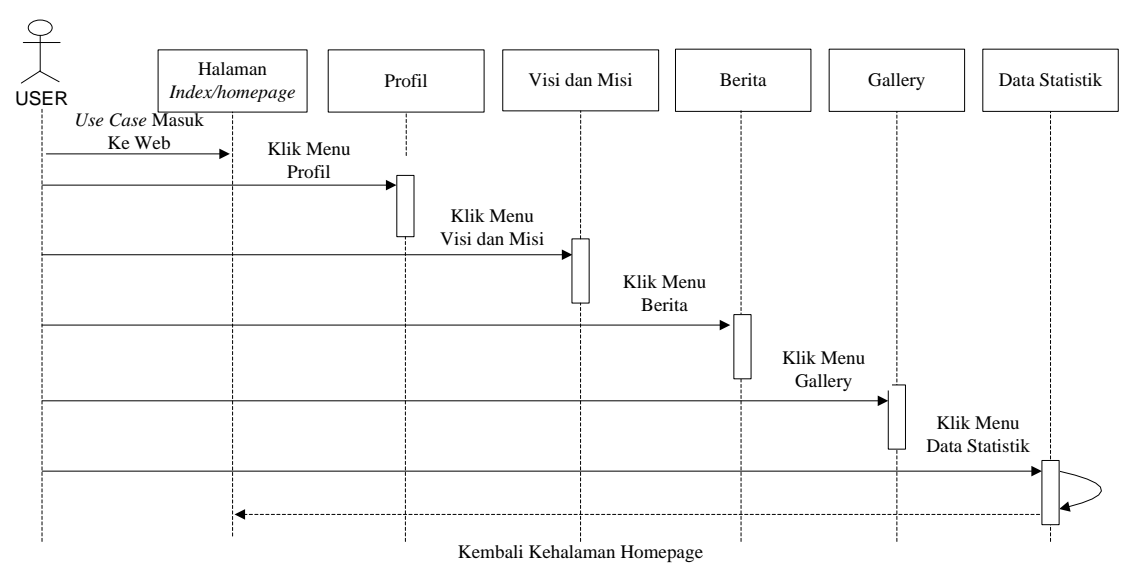

Gambar 5. Aktivity Sequence Diagram

\section{F. Rancangan Terinci}

Rancangan terinci ini menjelaskan tentang rancangan ouput, rancangan input, struktur tabel, relasi tabel dan rancangan aplikasi. Dalam menjaga keutuhan dan melindungi web, admin terlebih dahulu harus menggunakan namauser dan password. Hal ini bertujuan agar tidak sembarangan orang dapat mengutak atik isi web. Setelah admin berhasil login admin web, maka admin dapat mengisi web baik berupa teks, gambar, video dan lain-lainnya. Rancangan dan desin web Monografi pada Kecamatan Singingi dapat digambarkan berikut ini.

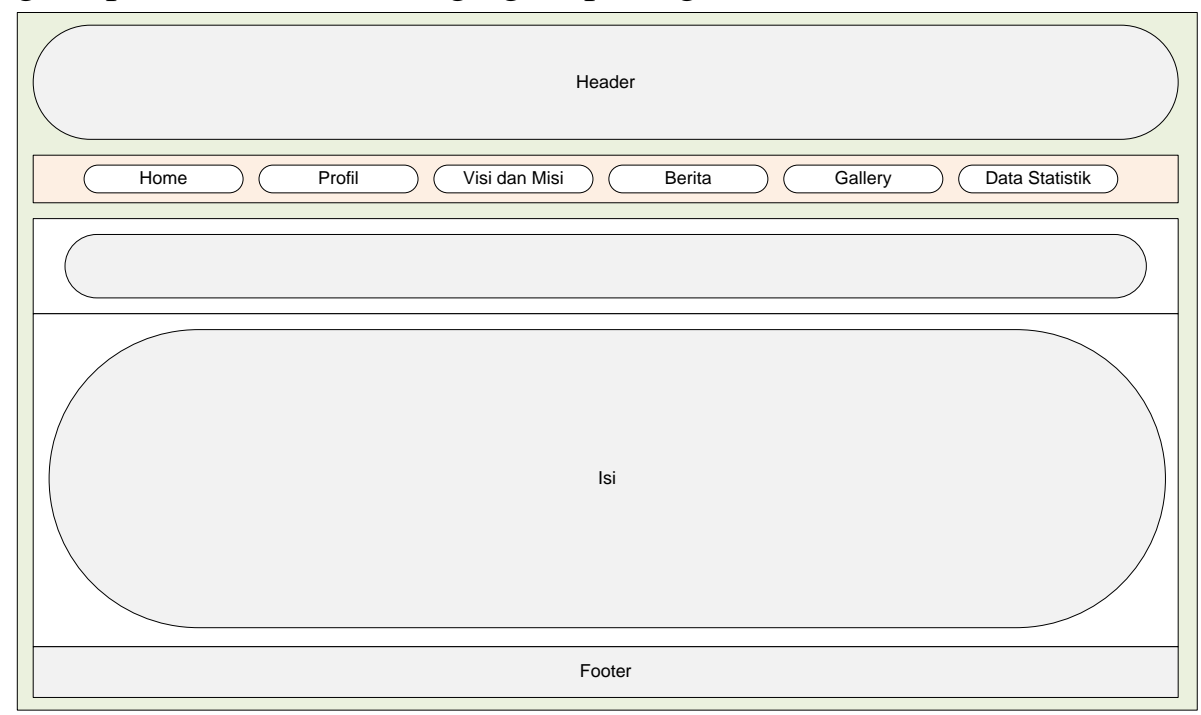

Gambar 6. Rancangan Website 
Volume 3 Nomor. 1, April 2018

P -ISSN : 2541-1179, E-ISSN : 2581-1711

Ojs :http://journal.uin-alauddin.ac.id/index.php/instek/index

Email : instek@uin-alauddin.ac.id

NEORUATKASA IS DAN TENOOCOE

\section{G. Implementasi Program}

1. Tampilan Halaman Profil
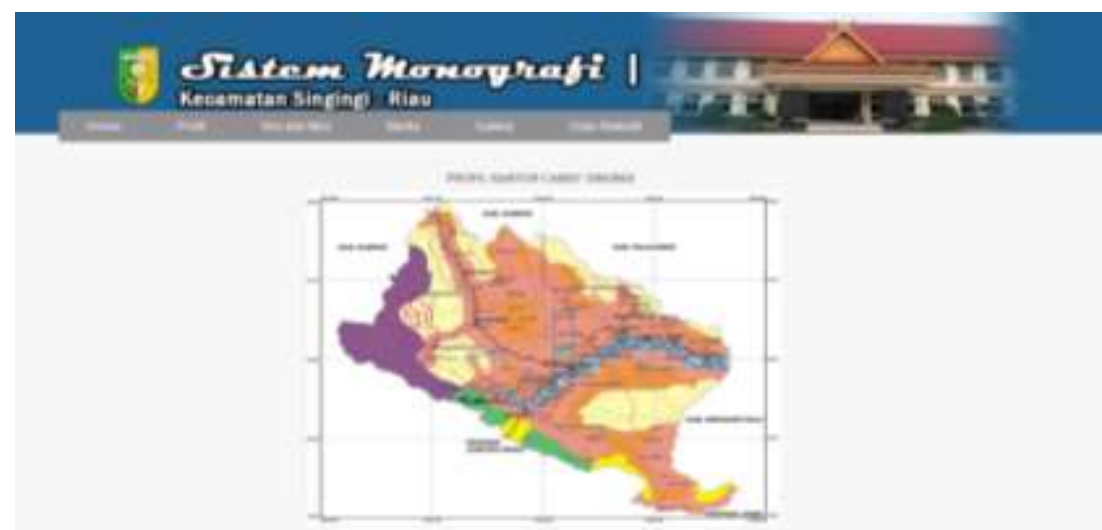

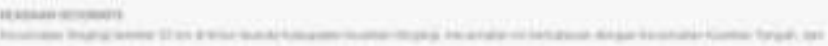

Gambar 7. Halaman Profil

2. Tampilan Halaman Visi dan Misi
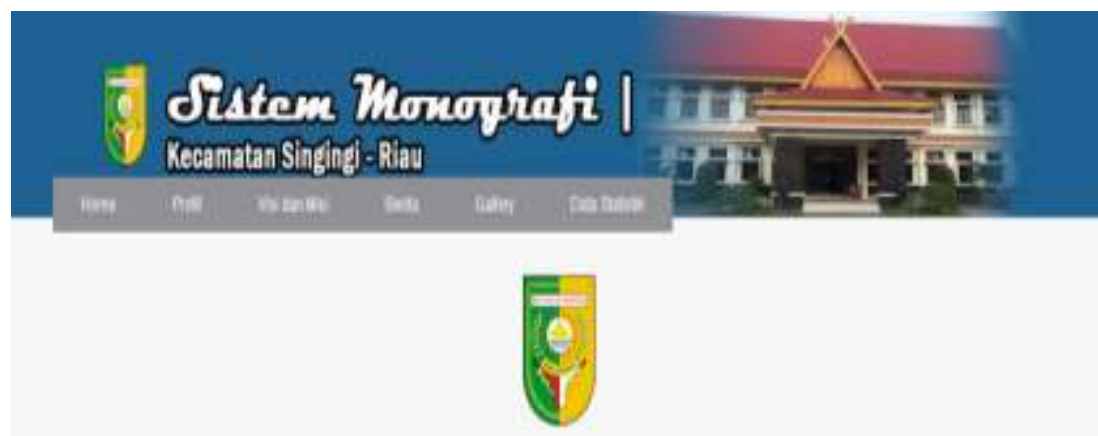

Wuntalese

vatokensas soge

Mis

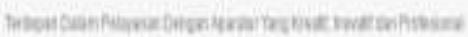

tain

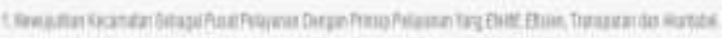

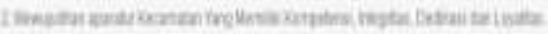

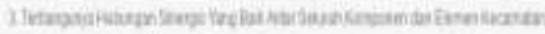

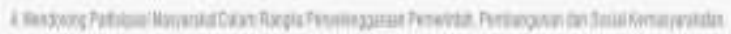

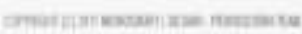

Gambar 8. Halaman Visi dan Misi 
Volume 3 Nomor. 1, April 2018

P -ISSN : 2541-1179, E-ISSN : 2581-1711

Ojs :http://journal.uin-alauddin.ac.id/index.php/instek/index

Email : instek@uin-alauddin.ac.id

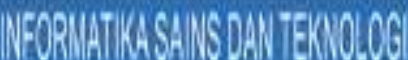

3. Tampilan Halaman Berita
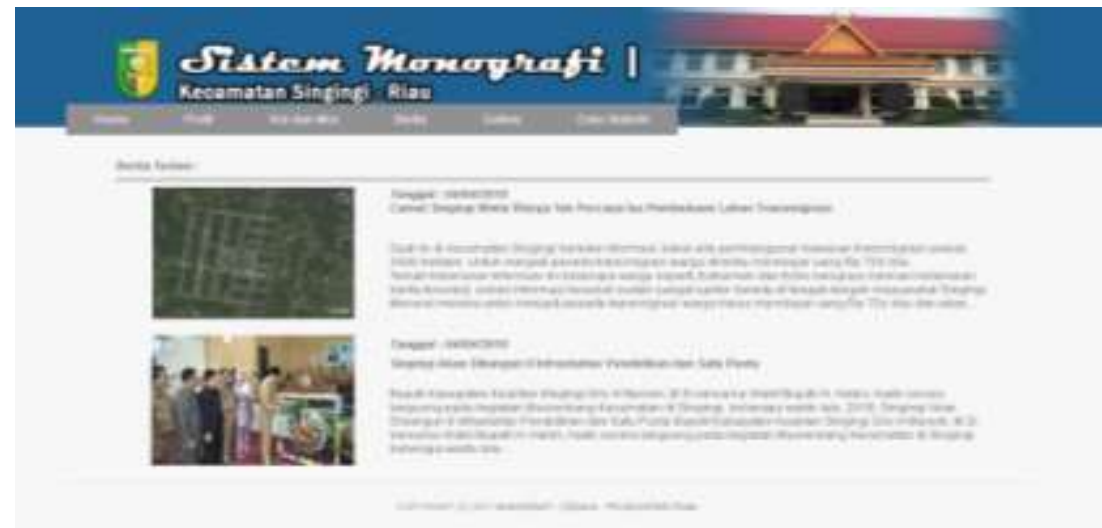

Gambar 9. Halaman Berita

4. Tampilan Halaman Gallery
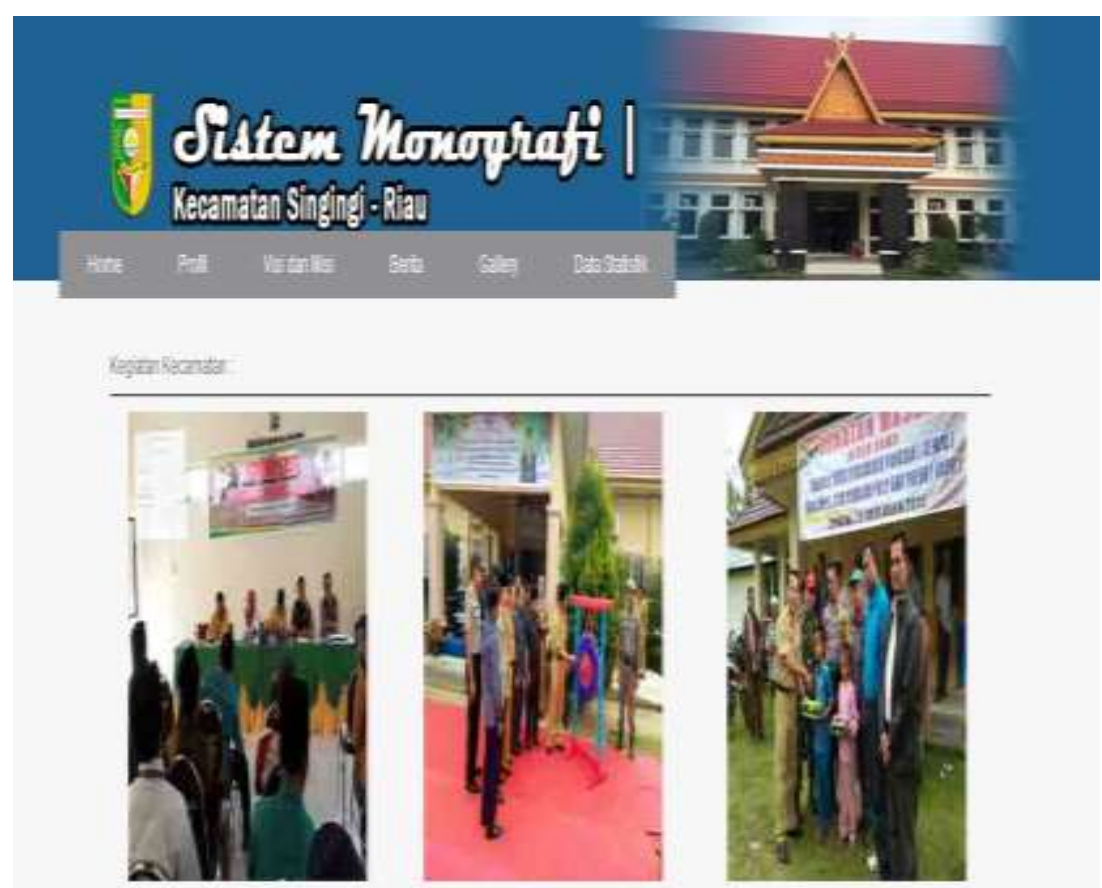

Gambar 10. Halaman Gallery 
5. Tampilan Data Statistik

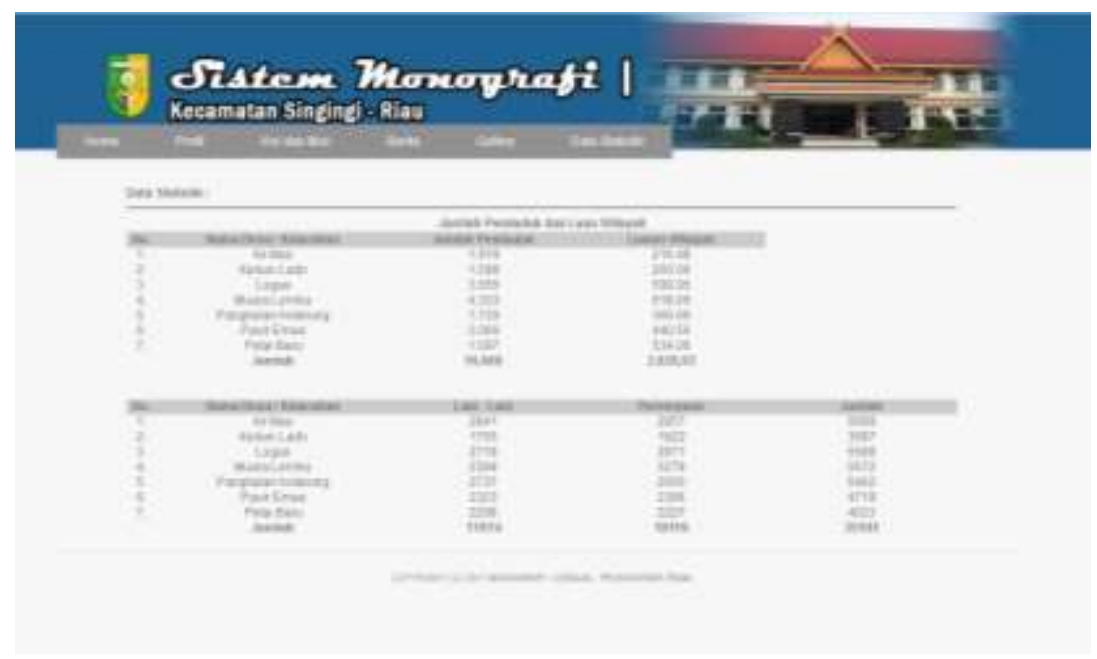

Gambar 11. Halaman Statistik

\section{PENUTUP}

\section{A. Kesimpulan}

Berdasarkan penelitian yang penulis lakukan tentang sistem informasi monografi pada Kecamatan Singingi, dapat disimpulkan :

1. Sistem informasi monografi tentang suatu data statistik penduduk dalam suatu wilayah.

2. Dengan adanya sebuah sistem informasi monografi masyarakat dapat mengetahui pertumbuhan dan perkembangan wilayah dalam bentuk data statistik.

\section{B. Saran}

Penulis menyadari masih banyak perbaikan-perbaikan maupun kekurangan dalam penelitian ini, oleh karena itu untuk pengembangan selanjutnya penulis menyarankan :

1. Dalam perancangan sistem ini mungkin belum maksimal dan dapat dikembangkan lagi menjadi lebih baik kedepannya.

2. Perlunya diterapkan di Kecamtan lainnya sehingga dapat memudahkan pihak luar dalam pencarian data tentang monografi 


\section{DAFTAR PUSTAKA}

Danang Juniarta, dkk. 2013. Perancangan Sistem Informasi Pelaporan Monografi Berbasis Web (Studi Kasus Pada Kantor Kecamatan Semarang Utara). Semarang. Journal Speed - Sentra Penelitian Engineering dan Edukasi - Volume 5 No 2 - $2013: 21: 30$.

Febri Haswan dan Nofri Wandi Al-Hafiz. 2017. Aplikasi Game Edukasi Ilmu Pengetahuan Alam. Teluk Kuantan : Riau Journal Of Computer Science Vol.3 No.1 Januari 2017 : 31- 40.

Jogiyanti, HM. 2002. Sistem Informasi Manajemen. Yogyakarta : Andi.

Maria Agustina, S. 2011. Adobe Dreamweaver CS5. Yogyakarta : Andi.

Riyanto Slamet. 2001. Belajar Cepat Photoshop Cs5. Jakarta : Seri Desain Grafis.

Sri Dharwiyanti, dkk. 2003. Kuliah Umum Ilmu Komputer. Jakarta : PT. Gramedia.

Syamsiah Siti. 2009. Mengenal Pemrograman HTML Sebagai Dasar Pembuatan Web. Yogyakarta : Bina Sarana. 